\title{
New Development Approaches for Higher Vocational Colleges in Guangdong from the Perspective of Supply-side Reform
}

\author{
Yihui Huang
}

Heyuan Polytechnic, Heyuan, Guangdong Province, China

Keywords: supply-side structural reform; higher vocational education in Guangdong; development path

\begin{abstract}
Supply-side reform is an important measure which can promote the economic development of our country. In China, Guangdong is a province with strong economic power. With the continuous promotion of reform, higher vocational institutions in Guangdong are bound to find out how to optimize the professional structure, deepen the construction of connotation, and train talents according to the demands of society. Combined with the structural reform of supply-side, this paper analyzes the current situation and problems in higher vocational education of Guangdong, and puts forward to a new way of reform and development.
\end{abstract}

\section{Introduction}

On November 10, 2015, Jin-ping Xi put forward to the concept of "supply side reform" for the first time at the Eleventh Meeting of the Leading Group for Financial and Economic Affairs. At the the Central Economic Working Conference of 2016, it was clearly proposed that, "in 2017, the structural reform of supply side should be deepened". At present, the structural reform of supply side has become a hot spot in the economic field of China, and become a new center of national economic development.

\section{The Economic Significance and Influence of Supply-side Structural Reform.}

In economics, the demand side mainly includes the "three carriages" of investment, consumption and export, while the supply side include factors such as labor, land, capital, as well as system creation and innovation. In the past few decades, the economic base of China is relatively weak; the supply is relatively insufficient. To solve people's increasing material and cultural needs, the state actively uses the traditional Keynes economic theory to stimulate and maintain the sufficient level of effective demand through fiscal and monetary policies, in order to roughly balance the overall social demand and total supply, and promote economic development. This policy has achieved considerable economic results. In 1979, the Party Central Committee and the State Council approved Guangdong and Fujian to implement "special policies and flexible measures" in foreign economic activities, and decided to build special economic zones in Shenzhen, Zhuhai, Xiamen and Shantou. By November 10, 2001, the Doha Conference of World Trade Organization approved our country as a full member. The economic system of our country has transformed from plan economy to market based economy. However, now the structural imbalance between supply and demand is increasingly prominent. On one hand, the quantity of the products produced by domestic enterprises has exceeded the demand capacity of the market; on the other hand, Chinese producers have made surplus middle and low end products but insufficient high-end products.

Under that background, the general secretary of Jin-ping Xi used the four operations of "addition, subtraction, multiplication and division" to lay out a new strategy of "promoting the supply side structural reform while moderately expanding total demand, and improving the quality and efficiency of the supply system”, which provided a new approach on the economic development of China in the new time period.

The first issue of supply side structural reform is to optimize the supply system, which means to 
provide high quality products and services. The second issue is to optimize the structure, which means to expand effective supply, reduce the output of low-end products and increase the supply of high-end products, so as to better meet the needs of modern people in uplifting living standards. On that basis, we can promote the sustained and healthy development of economy and society. At present, many scholars have pointed out that, "the new concept of the supply side shows the new cognition in macroeconomic policy, and points out the trend and focus of macroeconomic policies in the future. The concept of supply side provides us with a new perspective to understand China's economic policies and economic prospects.” By reviewing the theoretical exploration and relevant experience of supply side reform, and analyze the current situation of Chinese economy, we can grasp the starting point, the internal logic and the advancing field of supply side reform more clearly, and deepen its significance on China's economy. ”

\section{The Connotation and Enlightenment of Supply-side Structural Reform in Higher Vocational Education}

The structural reform of supply side is the focus of our country's economic work. It is an essential task in the first year of the "13th Five-Year Plan"; it constantly affects the development of all walks of life in our country. As the "first productive force", science and technology are important impetus which promotes its development. Higher vocational education is the most direct and powerful factor which can accelerate the modernization of material production technology in modern society. How to adapt to various changes under the adjustment of economic environment and industrial structure is a new problem we must face.

\subsection{The connotation of supply-side structural reform in higher vocational education.}

From literal meaning, the word of supply side structural reform can be divided into three parts: supply, structure and reform. From this perspective, the structural reform of supply side in higher vocational education can be summed up as follows points. The first point is supply, which means to improve the quality of resource supply, namely the quality of personnel training. In the new period, higher vocational education should reform talent training mode to improve the comprehensive quality and professional ability of talents, and cultivate talents who can meet the needs of society under the new situation. The second point is structure. A rational resource allocation structure is needed, including the professional structure, curriculum structure and faculty structure. Through the optimization of structure, available resources of higher vocational education can be used to the largest extent. The third point is reform, which means to break the old one and build the new one. On the basis of continuous optimization of higher vocational education structure, teaching mode and teaching methods need to be innovated to improve the overall teaching effect and output effect, so as to provide innovative and technical talents for all kinds of enterprises in the new period of economic reform.

\subsection{The enlightenment of supply-side structural reform to higher vocational education in Guangdong.}

Guangdong Province is a strong economic province of China. In GDP ranking list of 2016, the economic aggregate of Guangdong was 7951.205 billion yuan, with 7.5\% increase over the previous year. At the same time, achievements have been achieved in supply side reform such as cutting capacity and inventory, deleveraging, cost reduction and improving weak links.

At the same time, with the continuous expanded influence of "supply side" of economy, citizens in Guangdong are also exploring and innovating in this field. Higher education institutions are active in cultivating more high level and high skilled personnel. From 2011 to 2015, Guangdong kept the priority of education development, insisted the strategic policy of promoting economy by education, and further strengthened top level design as well as overall planning. We should actively coordinate the forms and methods of education in various regions, increase investment in education, and earnestly implement the policy of "precise poverty alleviation". These methods can effectively promote the coordinated development of education in the whole province, and greatly lift the quality 
and level of regional education development. [1]

As a part of higher education, higher vocational colleges also take the important responsibility of supply side reform. They also need to explore and innovate their own ways. From the Annual Report on the Quality China's Higher Vocational Education of 2017 published in July 15, 2017, we can see that 9 colleges and universities in Guangdong list in the top 50 higher vocational colleges and rank high. On the basis of maintaining the position of strong economic province, Guangdong is gradually becoming a strong education province.

With the continuous promotion of reform, higher vocational institutions in Guangdong are bound to find out how to optimize the professional structure, deepen the construction of connotation, and train talents according to the demands of society. Combined with the structural reform of supply side, this article analyzes the current situation and problems in higher vocational education of Guangdong, and puts forward to a new way of reform and development.

\section{The Current Situation and Problems in Supply-side Reform of Higher Vocational Colleges in Guangdong}

According to the Annual Report on the Quality China's Higher Vocational Education of 2017, at the end of 2016, there were 4 more vocational colleges in Guangdong province than in 2015. The total number of full-time vocational students in Guangdong increased by 21 thousand compared with 2015, with the increase rate of nearly $3 \%$. The numbers of planned enrollment and enrolled students also increased. In 2016, the employment rate of higher vocational graduates was $95.75 \%$. The proportion of local employment graduates was $60.76 \%$, increased by $1.66 \%$ compared with 2015 ; the proportion of graduates who work in basic service agencies and small, medium enterprises was $77.27 \%, 4.02 \%$ higher than that of 2015; the ratio of graduates who work in key state enterprises was $11.49 \%, 2.38 \%$ higher than that of 2015. From these data, we can see that the quantity of higher vocational education graduates is rising, and can basically meet the market demand.

But facing the arduous task of accelerating the economic transformation and upgrading, the motive of economic development should be rapidly transformed from resources and low cost labor force driven to innovation driven. Innovation driven development requires high-quality workers and professionals with innovative spirit and abilities; these qualifications could only be cultivated through education. There is a gap in the scale and quality of existing innovative and technical talents and the requirements of innovation driven development.

\subsection{Quality of products and services.}

First, the supply of high quality is insufficient. The high quality products and services provided by higher vocational education means excellent technical talents, remarkable scientific development results, as well as good services which can meet the requirements of innovation driven economy of enterprises and the society. However, the rapid development of economy in our province is combined with high quality talents short supply. High quality and high-tech talents are always favored by enterprises. It was reported that Zhi-qiang $\mathrm{Li}$, the deputy secretary of the Party Committee of Guangzhou Railway Company, once led a recruitment team with 9 members to Wuhan, and provided 800 positions to graduates of Wuhan Railway Vocational College of Technology. Many large enterprises, such as Haitian and Yili, went directly to higher vocational colleges in our province and directly hire outstanding professional reserve cadres, such as students major in electromechanical integration and digital control technology before they graduate. All these facts show that high-quality and high skilled talents are in short supply.

Second, the supply of low quality is surplus. Low quality products and services provided by higher vocational education refer to mediocre trained personnel, low end scientific development results and poor quality social services which cannot meet the needs of economic society and innovation driven development. According Annual Report on the Quality China's Higher Vocational Education of 2017, employers had relatively low satisfaction levels on the "problem solving", "professional knowledge and skill” and "organizational ability" of higher vocational college graduates in Guangdong. In the long run, it is still an important factor that affects the development of higher vocational education in 
our province and even the long-term development of economy.

\subsection{Structural problems in professions and curriculum.}

First is the problem of professional structure. Guangdong province is a strong economic province. According to data analysis of 500 strongest enterprises in Guangdong Province in 2017, manufacturing enterprises accounted for 49.8\%; service industry (including circulation industry) accounted for $48.6 \%$, among which there were many technology intensive services and high quality service enterprises; comprehensive enterprises accounted for $1.6 \%$. The data shows that the economy of our province is changing from the industrial leading economy to service-oriented economy. According to characteristics of economic development, some vocational colleges in Guangdong are actively adjusting their professional structures. For example, according to economic growth points and the survey on job requirements, Shenzhen Institute of Information Technology set up “optoelectronic technology application”, “decorative art design” and other majors in recent years. The proportion of students who major in electronic information from 2015 to 2016 was 42.44\%; 93.54\% students in school are major in subjects which are correspond to four major pillar industries of Shenzhen; 51.19\% students are specialized in high-tech industries. [2]

However, before the concept of structural reform of supply side is put forward, the professional constructions of most vocational colleges are not suitable for regional economic development. It is reported that although our province has the largest scale of vocational education in China, the layout of professional setting is not optimistic. The professional setting is irrational and cannot meet social demand. The five majors with the highest repetition rates are accounting (74), business English (65), computer science and technology (64), logistics management (58) and e-commerce (53). The data also shows that the professional setting of higher vocational colleges cannot adjust to regional industrial structure development; the problem of structural shortage is serious. Majors related to third industry were more than $19.51 \%$ of industrial demand, while major related to second industry was in short supply by $14.51 \%$. [3]

Second is the structural problem of curriculum. At present, the higher vocational education in our country is still in specialized level. Facing the requirements on high level skilled talents, higher vocational colleges continue to explore new talents training modes. Colleges can adjust curriculum system, and carry out " $3+2$ " segmental training mode with undergraduate colleges. However, the curriculums of higher vocational education are different from traditional theory courses; they are practice curriculums related knowledge learning and aim to cultivate the professional skills and accomplishments of students. Therefore, there are many problems in the course setting of higher vocational intuitions. For instance, there are more theoretical knowledge courses but less practical operating courses than actual needs. A more balanced, comprehensive and selective curriculum structure is needed.

\subsection{The development of teachers cannot meet the new needs of teaching.}

With the continuous popularization of higher education and the continuous expansion of educational models in China, the supply of high level talents is increasing, while teachers' recruitment threshold is uplifting. The academic degrees of teachers in higher vocational education institutions are also changing. Heyuan Polytechnic in Guangdong is taken as an example. By the end of 2016, there were 722 teachers and staff in school, 322 of them have graduate or master's degree, accounting for $45 \%$ of all staff; $59 \%$ professional teachers have master's degree; the number of “double teachers" was 485 , accounting for $90 \%$ of full-time teachers.

But the common problem in most vocational colleges is that, the level of teachers is improving, but the structure is not optimized. Under the environment of supply side reform, the development of teachers in higher vocational colleges is not suitable for the needs of practical teaching under the new environment. First of all, most of the new teachers are graduating masters or Ph. D. They are lack of practical teaching experience and work experience. Secondly, excellent talents such as skilled craftsmen introduced from enterprises have strong practical abilities, but they cannot adapt to the current system of teacher promotion through scientific research achievements. Finally, the teacher training mechanism in higher vocational colleges is also deficient. The school encourages teachers to 
train, practice and carry out social services. However, the incentive, assessment and workload conversion of this participation cannot be well matched. The supply of school teachers cannot keep up with market demand.

\section{A New Way to Develop the Supply-side in Guangdong Higher Vocational Colleges}

In view of the world situation, a powerful country must attach importance to education. Today's education has entered the era of strategic planning. Higher education has also gradually shifted from the previous scale and extension development to connotation development. As an important supply side of educational products, higher vocational colleges should actively explore ways to adapt the new environment and new requirements, actively promote the process of reform, and improve the supply quality to solve various structural contradictions.

\subsection{Optimize the level structure of talent supply and promote the development of connotation.}

The first strategy is to deepen the reform of talent training mode. Under the background of economic structural reform, we should further clarify the training objectives and specifications in accordance with social demands on talents' quality and quantity, trying to make the teaching process suitable, adjust the professional and curriculum structures, change teaching and curriculum ideas, use teaching methods which are adapted to the practice, and perfect teaching management and evaluation mechanisms. Colleges should also try to improve the quality of education and teaching, so as to provide students with high level resources and cultivate talents with high professional skills.

The second strategy is to strengthen quality education and promote the connotation development of higher vocational education. Higher vocational education should not be regarded as the supplement of undergraduate colleges and universities; to increase the enrolment rate of high school is not the main task of higher vocational education. On the basis of development concepts of innovation, coordination, green, open and mutual-share, higher vocational institutions should give full play to their technical advantages, trying to improve the cultural quality and comprehensive quality of students. The final goals of higher vocational institutions include, to improve the supply side structure of education industry in Guangdong Province, to meet the talent demands of enterprises and industries under the new economic environment, and to realize the balance between supply and demand of high quality products and survives.

\subsection{Improve the quality of research results and promote the integration of production and education.}

The first measure is to strengthen the scientific research power of higher vocational colleges. On one hand, we should improve the incentive mechanism, encourage teachers to take part in various academic seminars, and accumulate practical experience. Teachers should combine theory with practice to improve the quality of their scientific research results. The method can not only strengthen the scientific research power of schools and improve the level of teachers, but also provide high quality academic fruits for the society. Academic achievements can help middle and low end enterprises to become high end enterprises. On the other hand, both soft and hard measures should be taken in this process; high-level scientific research talents from other colleges and skilled craftsmen from enterprises should be hired to enrich the scientific research team of vocational colleges.

The second measure is to deepen the innovation and entrepreneurship education. Vocational colleges and universities should be integrated into regional technological innovation system. Vocational colleges and enterprises need to establish communities composed of innovative talents with technological skills. Through school enterprise cooperation and integrated engineering, we can form a multidimensional model which is based on schools, promoted by the government, guided by industries and participated by enterprises. A modern "Guangdong mode" on vocational education with production and education integration, school and enterprise cooperation and coordinated development can be established. 


\subsection{Optimize strategic structural layout and improve modern vocational education system.}

First is to optimize the structure of higher vocational education layout. Under the background of supply side structural reform, higher vocational education in our province also needs to carry out structural optimization according to the requirements of industrialization development and new urbanization. On one hand, in the new economic environment, the provincial government should strengthen the communication and co-ordination between different municipal governments, understand and master the advantages and disadvantages of each city in economic and talent development. The layout of vocational colleges should be combined with the development of competitive industries with local characteristics. Talent and intelligent resources provided by higher vocational colleges should also be used to promote the development of local economy. On the other hand, we should help to integrate regional resources and vocational education, so that to raise the overall level of higher vocational colleges in our province to a new level.

Second is to optimize the structure of higher vocational education. We need to promote the continuous improvement of vocational education system, and integrate various resources of secondary vocational schools, higher vocational colleges, adult colleges as well as graduate and undergraduate universities and colleges together. Efforts should be made to build a united training system from secondary vocational school, higher vocational school, as well as colleges and universities. Secondary vocational school, higher vocational college, applied technology universities and open universities need to work together to cultivate talents with knowledge and technical skills. At the same time, we should actively carry out international exchanges, in order to broaden our international horizons and promote the internationalization of colleges. For example, Heyuan Polytechnic in Guangdong has signed cooperation agreements with 11 colleges and universities in Taiwan, and established cooperative relations with internationally well-known universities like the University of Connecticut and the University of Maryland in the United States, and Central Queensland University in Australia; joint personnel training models like "happy 3+1" and " $2+2$ " have been established.

\section{Conclusion}

Today, the focus of socialist market economy reform has transformed from demand side to supply side. Through the implement of the "addition, subtraction, multiplication and division" strategy, it is possible for China to adjust the supply side structure and achieve the sustainable and healthy development of economy, and realize the great rejuvenation of the Chinese nation.

The supply side reform of higher vocational colleges and the supply side reform in the economic field have both connection and difference. It is the responsibility of every higher vocational college to grasp the essence and task of supply side structural reform, to give full play to their own characteristics and functions, to build "higher vocational colleges with characteristics" under the new economic situation, and train highly qualified and highly skilled professionals for the society.

\section{References}

[1] Department of Education of Guangdong Province, Thirteenth Five-Year Plan of Education Development of Guangdong (2016-2020). 2017.01

[2] Department of Education of Guangdong Province, Annual Report on the Quality China's Higher Vocational Education of 2017. 2017. 01.

[3] Y. Lei, Arbitrary major setup and abolishment in part of professional colleges and universities. News Guangdong, 2014.11.04

[4] R. Feng, On the supply side reform in higher vocational colleges, in: Collected Third Award Papers in Annual Academic Meeting of Liaoning Institute of Higher Education in 2016 and the Seventh Session of Young and Middle-aged scholars Forum.2016.12 
[5] J.J. Bi, Practice of the supply side reform in the new teaching practice of higher vocational colleges, in: Collected Third Awards Papers in Annual Academic Meeting of Liaoning Institute of Higher Education in 2016 and the Seventh Session of Young and Middle-aged scholars Forum.2016.12

[6] Y.Y. Wu, S.P. Tong, Explore the new path of supply side reform in higher vocational colleges, J. Higher Education in Jiangsu. 5 (2016).

[7] Q. Hua, Q.Q. Ceng, Optimize the structure of higher vocational education under the supply side reform, J. Education and Vocation. 13 (2016). 